\title{
Some Experience in the Use of Damage Mechanics to Simulate Crack Behaviour in Specimens and Structures
}

Link to publication record in Manchester Research Explorer

\section{Citation for published version (APA):}

Bilby, B. A., Howard, I. C., Sheikh, M., \& Li, Z. H. (1995). Some Experience in the Use of Damage Mechanics to Simulate Crack Behaviour in Specimens and Structures. International Journal of Pressure Vessels and Piping, 64(0), 213-223.

\section{Published in:}

International Journal of Pressure Vessels and Piping

\section{Citing this paper}

Please note that where the full-text provided on Manchester Research Explorer is the Author Accepted Manuscript or Proof version this may differ from the final Published version. If citing, it is advised that you check and use the publisher's definitive version.

\section{General rights}

Copyright and moral rights for the publications made accessible in the Research Explorer are retained by the authors and/or other copyright owners and it is a condition of accessing publications that users recognise and abide by the legal requirements associated with these rights.

\section{Takedown policy}

If you believe that this document breaches copyright please refer to the University of Manchester's Takedown Procedures [http://man.ac.uk/04Y6Bo] or contact uml.scholarlycommunications@manchester.ac.uk providing relevant details, so we can investigate your claim.

\section{OPEN ACCESS}




\title{
Some experience in the use of damage mechanics to simulate crack behaviour in specimens and structures
}

\author{
B. A. Bilby, I. C. Howard, Z. H. Li and M. A. Sheikh
}

Sheffield University, Sheffield, UK

\section{INTRODUCTION}

Damage mechanics offers the possibility of representing the failure of components directly, without the use of characterising parameters such as the $K$ or $J$ of fracture mechanics. It does so by allowing the material to develop damage and fail at the level of the continuum mechanics description. Within the regime of ductile fracture, the method tries to encapsulate the loss of strength associated with void growth around the most significant second phase particles. Figure 1 illustrates diagramatically the process of void growth and the encapsulation of it in a 'cell' which represents at the continuum level the complex mechanics evolving within it as the cell softens and fails. Damage mechanics models these complex processes by building into the material constitutive equations the terms that represent the cell softening.

The technique has been used successfully at Sheffield ${ }^{1,2}$ to predict some of the spinning cylinder tests performed at AEA Risley. ${ }^{3}$ Figures 2 and 3 show the damage mechanics predictions for cylinders 1 and 3 in comparison with the experimental data and that from laboratory compact specimens. The enhancement of tearing resistance in the cylinders is correctly predicted directly from the computer simulation.

\section{DUCTILE DAMAGE MECHANICS}

We have effected the continuum mechanical modelling of this by incorporating in our finite element program TOMECH the damage mechanics formulation of Rousselier. ${ }^{4,5,6}$ This allows a description of ductile tearing behaviour based on the plastic potential $F$ and the yield criterion $F=0$. The resulting constitutive equations, derived using the normality rule ${ }^{4}$ are:

$$
\begin{gathered}
F=F_{\mathrm{h}}+F_{\mathrm{s}}, \\
F_{\mathrm{h}}=\frac{\sigma_{\mathrm{eq}}}{\rho}-R(p), \\
F_{\mathrm{s}}=D B(\beta) \exp \left(\frac{C \sigma_{\mathrm{m}}}{\rho \sigma_{\mathrm{Y}}}\right) .
\end{gathered}
$$

Here, $F_{\mathrm{h}}$ denotes the hardening term and $F_{\mathrm{s}}$ denotes the softening (or damage) term. The quantity $r$ is the material 


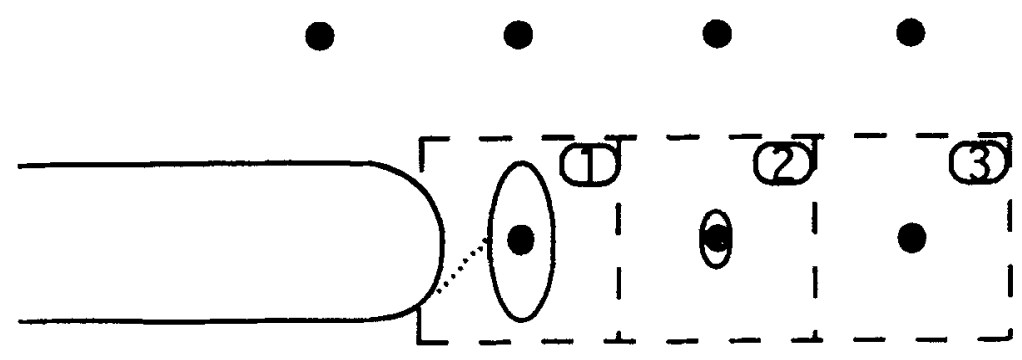

Fig. 1. Three cells are shown ahead of a crack tip. Cell 1 is so damaged by void growth that it is just about to fail, in this case by forming a shear band towards the crack tip. Cell 2 is deforming where the effects of material hardening and cell softening are comparable. Cell 3 is yet to reach the stage of significant softening.

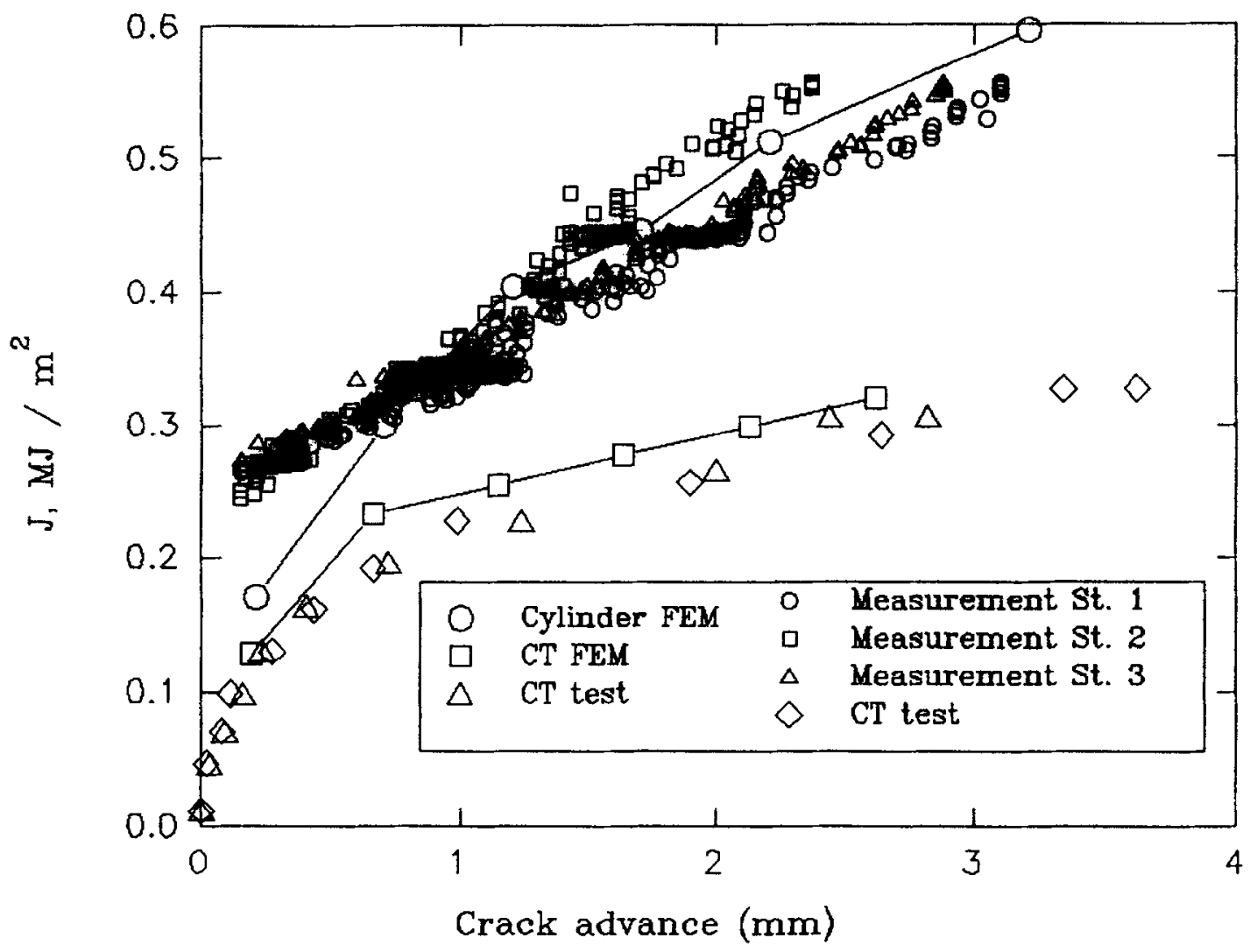

Fig. 2. Comparison between the damage theory predictions and experiment for the crack growth resistance data for spinning cylinder 1 . 


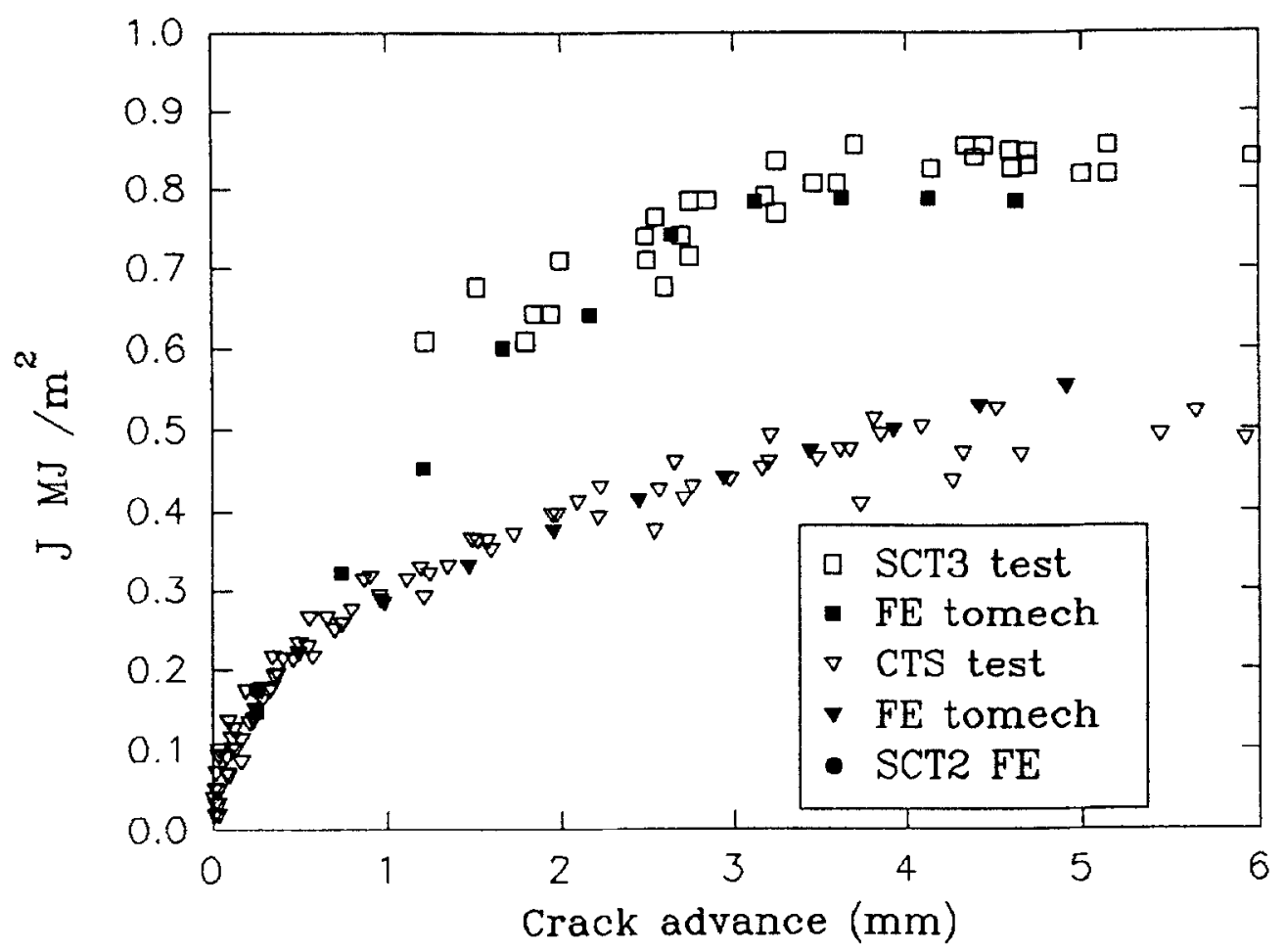

Fig. 3. Comparison between the damage theory predictions and experiment for the crack growth resistance data for spinning cylinder 3 . Also shown is the predicted point for spinning cylinder 2 , just on the point of initiation of growth.

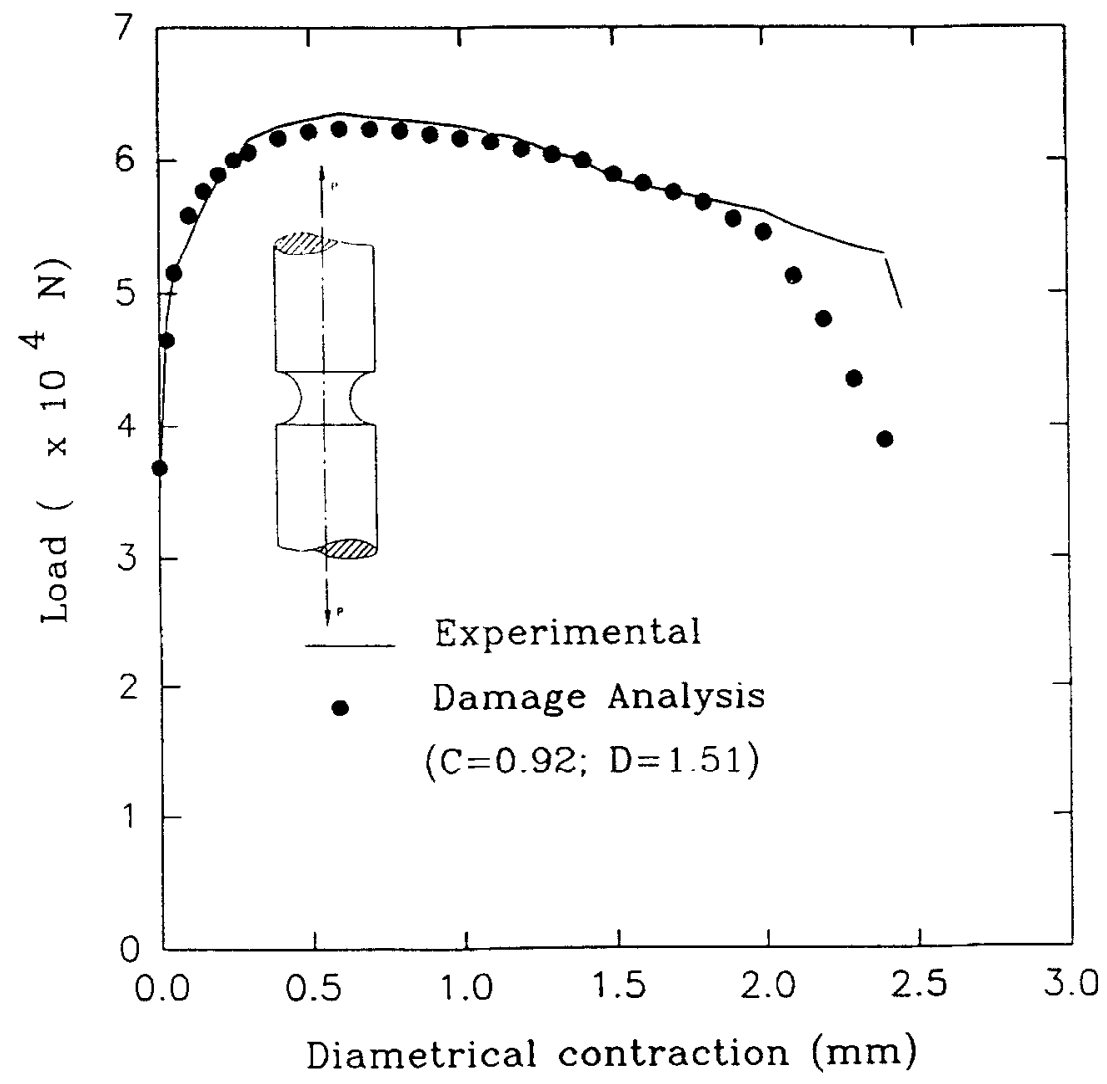

Fig. 4. Comparison between the experimental and tuned predictions for a $10 \mathrm{~mm}$ notched bar of the material of the NKS-3 experiment. 


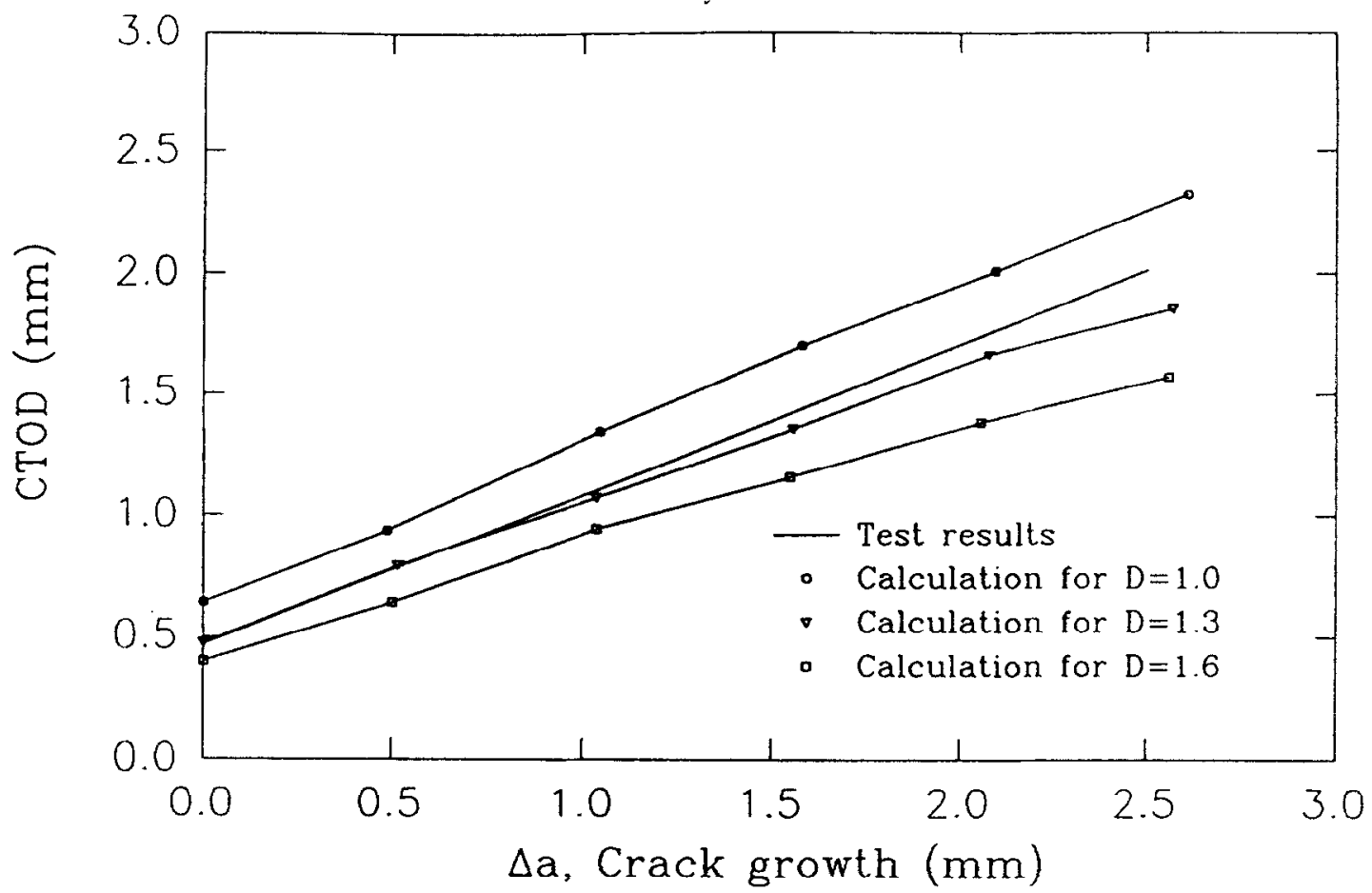

Fig. 5. Example of the numerical experiments performed to tune the damage parameters for the simulation of the Welding Institute wide plate tests. In the case shown, $C$ was fixed at 0.9 and the results compare the use of different values of $D$ with the mean experimental bend data.

density. $R(p)$ is representative of the material true-stress vs true-strain curve, $D$ and $C$ are constants, $s_{\mathrm{m}}$ is the mean normal stress and $s_{\mathrm{Y}}$ is related to the material flow stress. The term $B(b)$ is a function of the damage variable $b$, which is directly related to the current $(f)$ and initial $\left(f_{0}\right)$ values of the void volume fraction.

The evolution of damage in the above model reflects the competition between material hardening and softening behaviour. Thus, as loading is increased, the term $F_{\mathrm{h}}$ increases and reflects the increase in crack-tip stresses due to work hardening. With further increases in loading, $F_{\mathrm{s}}$ increases at the expense of $F_{\mathrm{h}}$ such that the crack opening stress $\left(s_{y y}\right)$ reaches a maximum and thereafter sharply declines. In conjunction with a finite element model, this effectively allows crack initiation and propagation to be modelled as a progression of discrete steps without recourse to the more usual technique of nodal release.

Because the above equations do not model the actual linking of voids as the material fails, a crack growth criterion based on stress is invoked. In this, the crack tip moves to the centroid of a cell (of size $L$ ) when the stress there reaches a maximum.

\section{CALIBRATION OF THE ROUSSELIER MODEL}

If damage mechanics is to be used to describe the behaviour of real components, the parameters $f_{0}, L, C$ and $D$, representing the mechanical effects of void growth, need to be chosen to model accurately the damage characteristics of the material from which the component is made. In common with others, we achieve this by tuning the parameters so that a selected group of laboratory tests are simulated with sufficient accuracy. Generally, $f_{0}$ can be estimated directly from metallographic examination of the material, or from its chemical composition and the use of Franklin's ${ }^{7}$ formula. The other three softening parameters must be chosen by trial and error using different values until close agreement is reached between analysis and experiment. Figure 4 illustrates the quality of agreement in a tuning of the notched tensile test data for the steel of the NKS-3 experiment to be described later.

\section{SOME EXAMPLES OF DAMAGE MECHANICS MODELLING}

\section{(a) Wide plate tests}

A uniaxial and a biaxial test were conducted by Garwood ${ }^{8}$ under contract to HSE in 1988. We have simulated the performance ${ }^{9}$ of these by tuning the material damage response to simulate the laboratory scale crack growth 
resistance data. Figure 5 shows the experimental data and the fitting of it with a damage mechanics model. Considerable numerical experimentation was involved in selecting the values of the damage mechanics parameters that represent the cell-averaged effect of the actual metallurgical damage that develops in the steel as deformation increases. With these tuned mechanical properties, a three dimensional model of the biaxial wide-plate tests could be produced. Figure 6 shows the development of damage in a simulation of a plate with the biaxiality ratio selected to simulate the constraint conditions appropriate to small scale yielding, whilst Figure 7 is a simulation of an equi-biaxial test. These figures also include a picture of the test specimens. The damage mechanics simulations correctly simulate the differing amounts of flat fracture in these two tests before the crack is dominate by the shear lips. The analyses show the variation of crack growth through the plate thickness in both tests, and the fact that both specimens displayed similar amounts of tunnelling at the earliest stages of growth. With further loading, more tunnelling occurs in the equi-biaxial specimen.

\section{(b) The NKS-3 cylinder}

This experiment ${ }^{10,11}$ was on a thick-walled hollow cylinder containing a circumferential flaw. The configuration and dimensions are shown in Fig. 8. The cylinder was loaded with an axial tensile load of $100 \mathrm{MN}$ and by pressurised water $\left(30 \mathrm{MPa}\right.$, at $\left.330^{\circ} \mathrm{C}\right)$ in the cylinder volume. These combined loads acting on the NKS-3 circumferential flaw simulated stress conditions similar to those near a longitudinal flaw in a nuclear PWR. Further loading came from a thermal shock applied by spraying cold water $\left(20^{\circ} \mathrm{C}\right)$ towards the inner cylinder surface through evenly distributed nozzles. The average crack extension was measured as about $3.6 \mathrm{~mm}$.

Damage mechanics parameters were obtained by tuning notched bar (e.g. Fig. 4) and $R$-curve data. An initial non-damage analysis gave the prediction shown in Fig. 9. A further analysis by damage mechanics predicted crack growth of about $3.2 \mathrm{~mm}$.

Table 1. Data from different mesh and cell models

(a) Values of $J\left(\mathrm{MJ} / \mathrm{m}^{2}\right)$ at initiation in a CT specimen predicted from two models of cells and meshes

\begin{tabular}{llllll}
\hline & $0.5 \mathrm{~mm}$ mesh & $0.25 \mathrm{~mm}$ mesh & $0.125 \mathrm{~mm}$ mesh & $0.0625 \mathrm{~mm}$ mesh & Average \\
\hline $\begin{array}{l}\text { Mesh size }=\text { cell } \\
\text { size }\end{array}$ & 0.1288 & 0.1005 & 0.0643 & - & 0.0979 \\
Error & $+32 \%$ & $3 \%$ & $-34 \%$ & - & - \\
Cell size fixed & 0.1321 & 0.1372 & 0.1278 & 0.1454 & 0.1356 \\
Error & $-2.63 \%$ & $+1.1 \%$ & $-5.8 \%$ & $+7.2 \%$ & - \\
\hline
\end{tabular}

(b) Comparison between the values of $J\left(\mathrm{MJ} / \mathrm{m}^{2}\right)$ at initiation in a CT specimen and in spinning cylinder 1 predicted from the mesh independent cell model

\begin{tabular}{llllll}
\hline & $0.5 \mathrm{~mm}$ mesh & $0.25 \mathrm{~mm}$ mesh & $0.125 \mathrm{~mm}$ mesh & $0.0625 \mathrm{~mm}$ mesh & Average \\
\hline CT specimen & 0.1321 & 0.1372 & 0.1278 & 0.1454 & 0.1356 \\
Error & $-2.6 \%$ & $1.1 \%$ & $-5.8 \%$ & $7.2 \%$ & - \\
Sp. cylinder & 0.1584 & 0.1493 & 0.1468 & 0.1397 & 0.1486 \\
Error & $6.6 \%$ & $0.5 \%$ & $-1.2 \%$ & $-5.98 \%$ & - \\
\hline
\end{tabular}



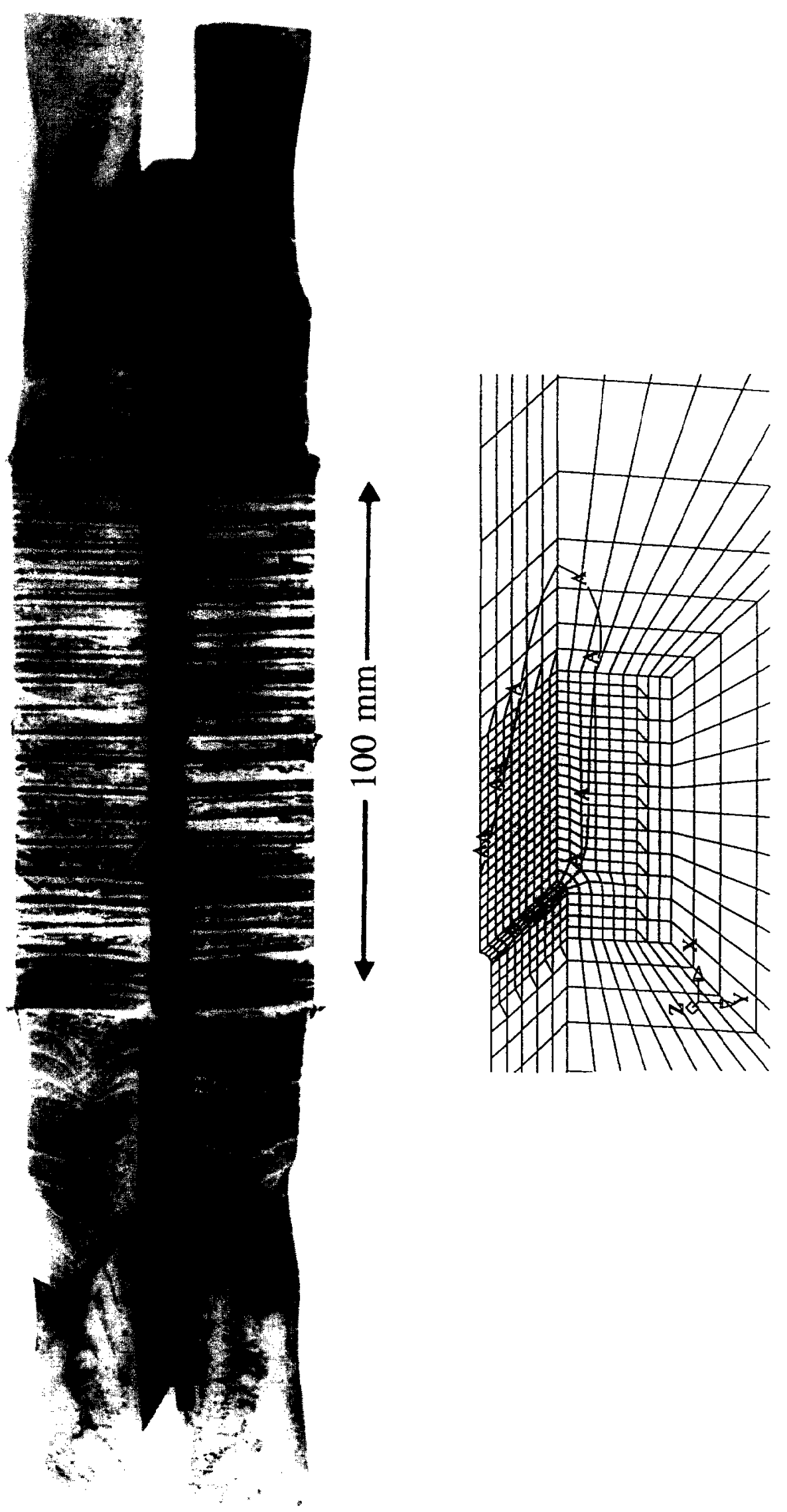

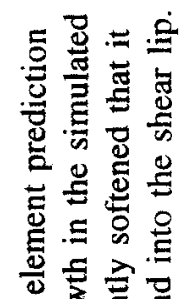

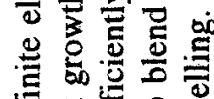

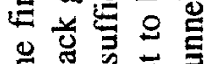

Ð它市吉

วิ

न

导

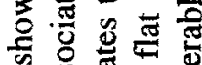

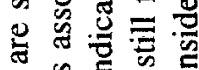

…

京焉总言

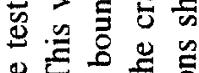

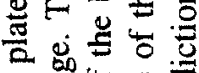

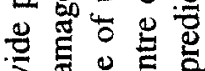

3 过 焉

求命空导

슴

Q

= $=$ क क

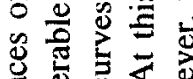

焉焉卷

氖害

总造芯

를

เ

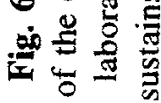



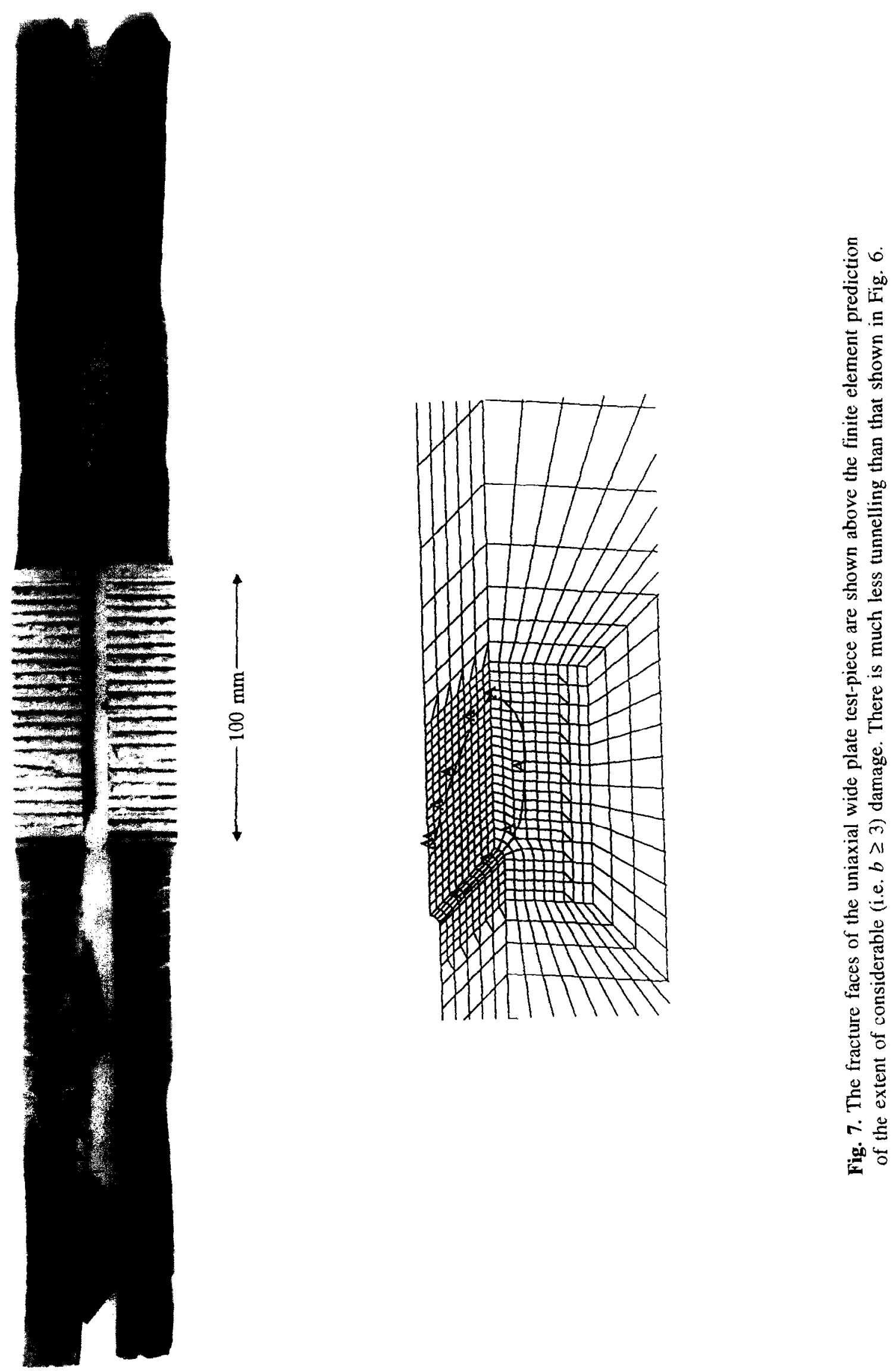


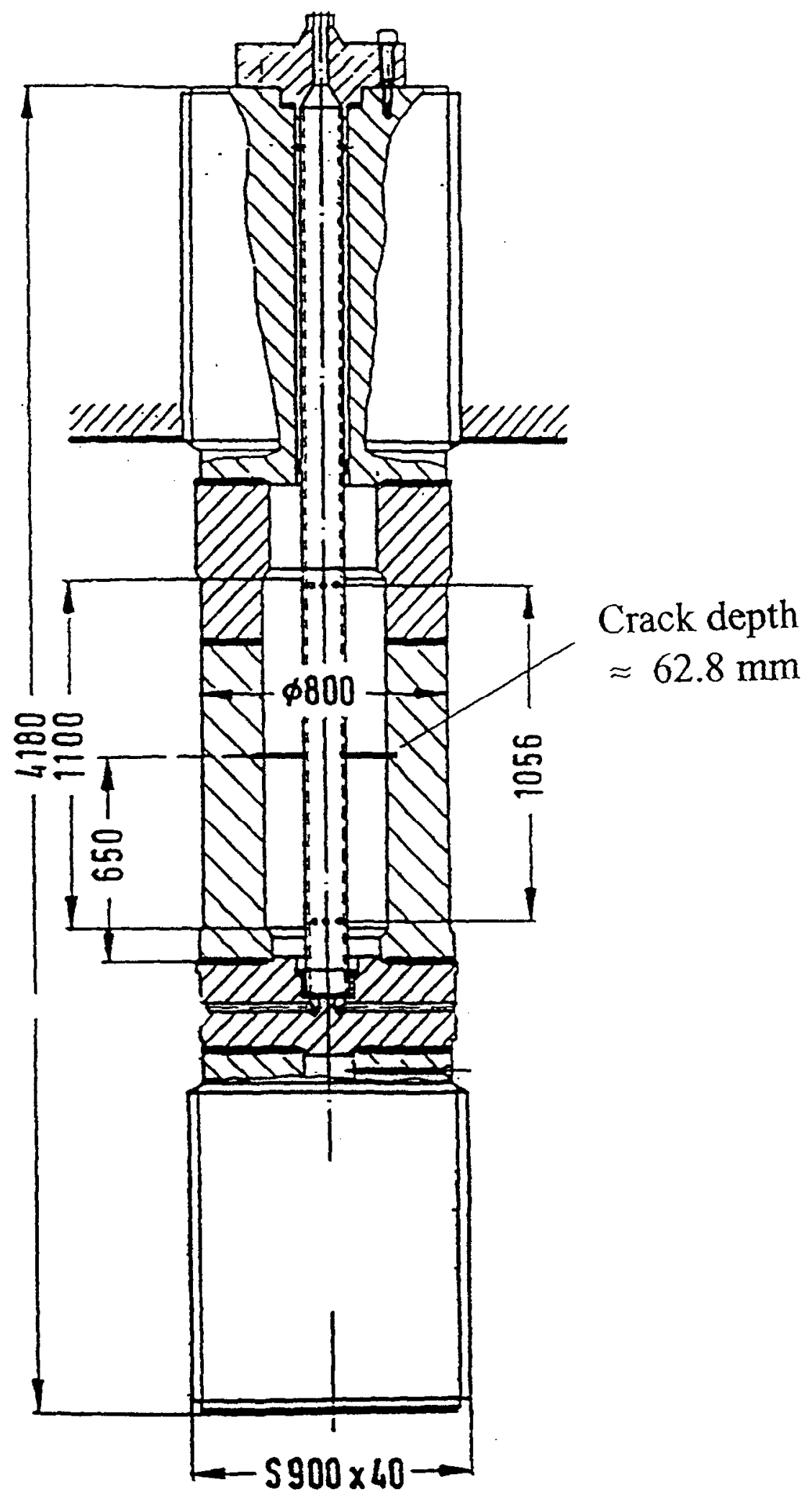

Fig. 8. The geometry of the NKS-3 experiment. 


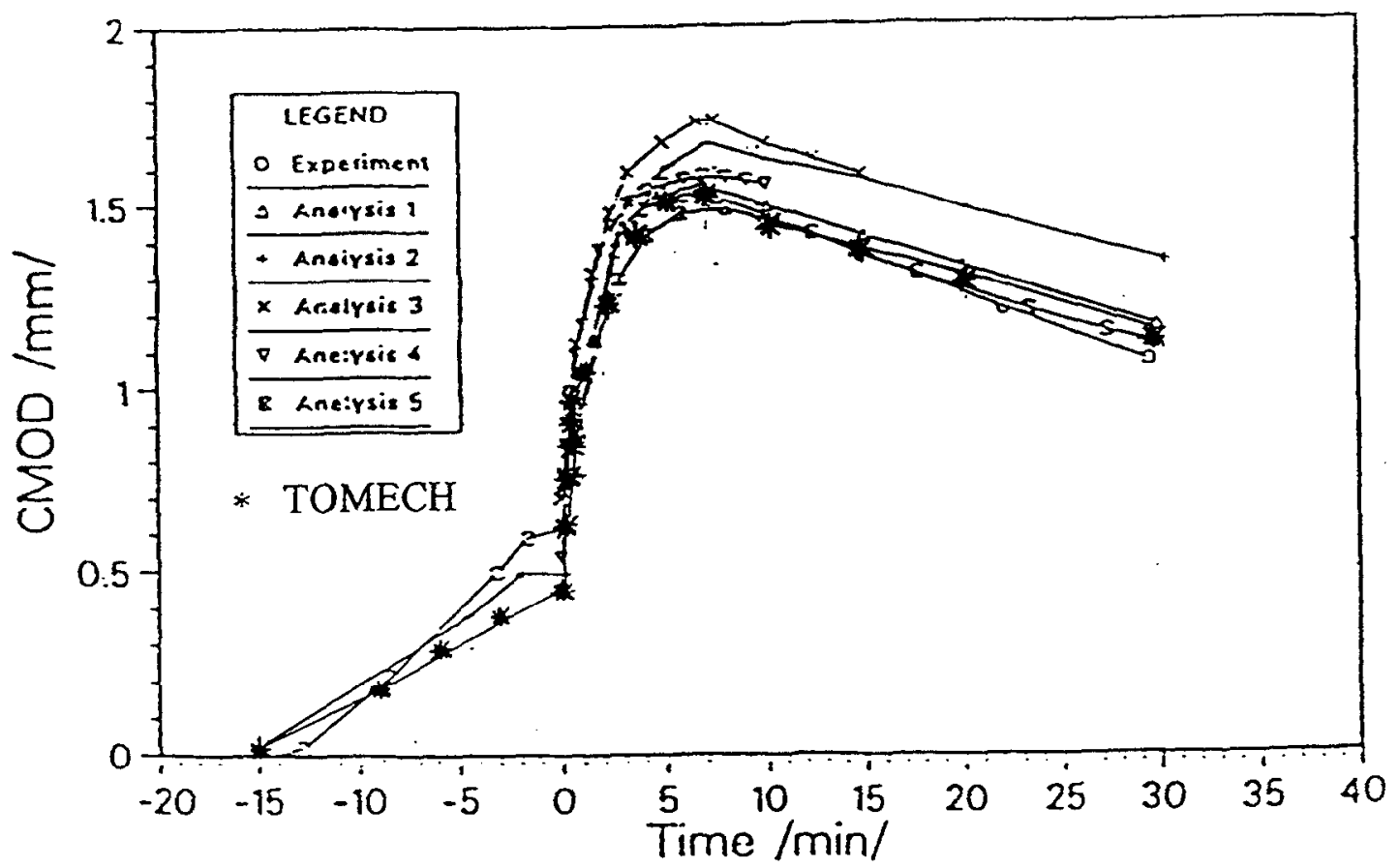

Fig. 9. A comparison between several analyses of the NKS-3 experiment and the observed (shown as -O-O-O-) change in crack mouth opening displacement during the test. The results of the SIRIUS analysis are indicated by

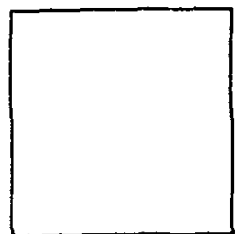

$L$
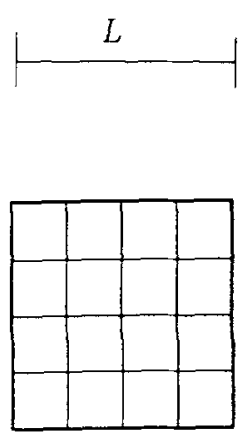

$4 \times 0.25 L$

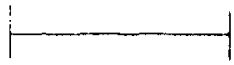

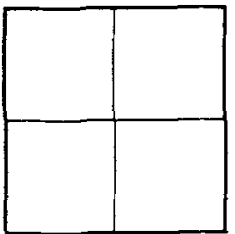

$2 \times 0.5 \mathrm{~L}$
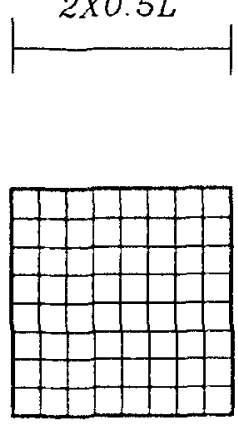

$8 \times 0.125 L$

Fig. 10. A cell, of length $L$, can be analysed with finite element meshes of reducing size. Shown here are four models starting from the conventional one where the cell and mesh are coincident, to one where the cell contains 64 elements. This allows the modelling of strain gradients within the cell prior to its attainment of significant damage. At this point the elements within the cell are forced to behave as one as the deformation develops further. 


\section{CELLS}

There is now considerable evidence ${ }^{12-15}$ that the mesh size to be used in the local approach assessment of cleavage should be less than the length of the characteristic volume $V_{n}$; typically, the mesh should be smaller than $50 \mathrm{~mm}$ for nuclear pressure vessel steels. On the other hand, the identification of the ductile damage cell size with that of the mesh in virtually all contemporary analyses of fracture using ductile damage mechanics produces mesh sizes of the order of $100-500 \mathrm{~mm}$ for the same type of steels.

It is clear that a sound model of fracture in the transition region must deal with both scales simultaneously. Recent work within SIRIUS ${ }^{16,17}$ shows that it is possible to de-couple the finite element mesh from the cell within which ductile damage emerges and grows. The model has been used to produce a mesh-independent damage theory analysis of crack initiation in both the first AEA spinning cylinder test ${ }^{3}$ and the compact data of the steel from which it was made. Figure 10 illustrates the relation between the fixed cells and the variable mesh size. Table 1 shows the effect of different models of mesh refinement. This either couples the mesh and cell or allows refinement only until a state of significant damage has been achieved in a cell, whereupon all the elements within that cell are forced to behave in the same way thereafter. The analysis strongly suggests that, even though the cylinder crack growth resistance curve if considerably steeper than that of the compact specimens, the initiation of crack growth occurred at approximately the same value of $J$ in each.

Li's models are the base on which a simulation of transition behaviour could be erected. The fine mesh within a cell whilst it hardens prior to the development of significant softening gives a sampling of stress on a scale appropriate to the cell size for cleavage. This can be input to a Weibull post-processor at any or every step in the analysis. Once significant ductile damage is sensed within the ductile damage cell, all elements within it are forced to behave subsequently in the same way. The stress in the cell reduces as damage develops, and the risk of cleavage recedes. But equilibrium demands, whilst this softening develops, that the reducing load is carried elsewhere. The stress in the mesh in the next most severely loaded ductile cell then needs to be sampled for stress and tendency to cleave. The process repeats until either a ductile instability ensues or a cleavage is triggered.

\section{REFERENCES}

1. B. A. Bilby, I. C. Howard and Z. H. Li, Prediction of the first spinning cylinder test using ductile damage theory, Fatigue \& Fracture Engng Mater. Structures, 16 (1992) 1-20.

2. B. A. Bilby, I. C. Howard and A. M. Othman, Contract Report: Simulation of large scale tests, Department of Mechanical and Process Engineering, University of Sheffield (1994).

3. D. J. Lacey et al., Spinning cylinder test 1 to 3: an investigation of upper shelf fracture behaviour in thicksection specimens (in 3 parts), AEA Thermal Reactor Services Report, AEA-TRS-4080, AEA Technology, Risley (February 1991).

4. G. Rousselier, Finite deformation constitutive relations including ductile fracture damage, in Three Dimensional Constitutive Relations and Ductile Fracture (Ed. Nemat-Nasser), North-Holland, pp. 331-355 (1981).

5. G. Rousselier, Ductile fracture models and their potential in local approach of fracture, Nucl. Engng Des., 105 (1987) 97-111.

6. G. Rousselier et al., A methodology for ductile fracture analysis based on damage mechanics, ASTM STP 995: Elastic Plastic Fracture, Vol. II (Eds J. D. Landes et al.), ASTM, Philadelphia, PA, pp. 332-354 (1989).

7. A. G. Franklin, Comparison between a quantitative microscope and chemical methods for assessment of non-metallic inclusions, J. Iron Steel Inst. 207 (1969) 181-186.

8. S. J. Garwood, Further tests under biaxial loading, Welding Institute Report 34018/1/88, The Welding Institute (1988)

9. I. C. Howard, Z. H. Li and B. A. Bilby, Ductile crack growth predictions for large centre cracked panels by damage modelling using 3-D finite element analysis, Departmental Report, Department of Mechanical and Process Engineering, University of Sheffield (1994).

10. A. Sauter, Recent progress in PTS research at MPA Stuttgart, French-German Seminar, Technical Presentation 1.4 (1987).

11. H. Huber, CSNI/FAG Project for fracture analyses of large scale international reference experiments (Project FALSIRE)-NKS-3 pressurized thermal shock experiment, CSNI-RE-1 (1989).

12. F. Mudry, A local approach to cleavage fracture, Nucl. Engng Des. 105 (1988) 65-76. 
13. P. Joly, Determination of the parameters $m$ and $s_{\mathrm{u}}$ of the Weibull model of pressure vessel steels: variability of the parameters, Presented at CEA-AEA Exchange Meeting on Methodology of the Local Approach, Risley (18-19 January 1994).

14. D. Moinereau, Testing of the steel clad mock-ups with CT-25 specimens and interpretation with various $m$ and $s_{u}$ parameters obtained, Presented at CEA-AEA Exchange Meeting on Methodology of the Local Approach, Risley (18-19 January 1994).

15. D. Moinereau, Complementary analysis with the Weibull model of the EDF testing of clad plates, Presented at CEA-AEA Exchange Meeting on Methodolgy of the Local Approach, Risley (18-19 January 1994).

16. Z. H. Li, Mesh independent cell models in continuum damage, Presented at a one-day Meeting of the SIRIUS Damage Group, Department of Mechanical and Process Engineering, University of Sheffield (10 December 1993).

17. B. A. Bilby, I. C. Howard and Z. H. Li, Mesh independent cell models for continuum damage theory, Departmental Report, Department of Mechanical and Process Engineering, University of Sheffield (1994).

\section{Question from M. Kirk, EWI}

Please provide more details on:

(1) Procedure for determining/back calculations of mechanics constants from experimental data.

(2) How the length scale is established.

\section{Answer from B. A. Bilby et al.}

The most critical of all the internal parameters of continuum ductile damage theory is the length scale over which the metallurgical processes of damage evolve. In most of our work we, like others, have represented this scale by the size of finite element in the region where damage is expected. Thus the current models depend on making a correct (or reasonable) choice for this element size. Its choice depends on a combination of studying metallographic data and performing numerical experiments. The spacing of the significant inclusions is the most important quantity in determining the length scale $L$. How to determine it directly from experimental observation is still an open question. However, one can start from simple relations connecting $L$ with the inclusion number $N_{\mathrm{v}}{ }^{\mathrm{A} 1}$ For the steels we have studied, these typically are of the form $L=k N_{\mathrm{v}}{ }^{-1 / 3}$, where $k$ lies between 2 and 5 . The constants $C$ and $D$ are determined by a process of trial and error calculation that seeks to simulate accurately the results of notched tensile and crack growth tests. Ideally, the notched-bar data should provide the relationship between load and notch root contraction. ${ }^{\mathrm{A} 2}$ But it is possible to obtain acceptable values for $C$ and $D$ when the notched-bar data are just for load/load point displacement, ${ }^{\mathrm{A} 1}$ and when there is no notched-bar data at all, from laboratory crack growth data only. ${ }^{\mathrm{A}}$ In practice, all this works as follows:

(i) The metallographic data allows a first estimate of $L$ to be made.

(ii) With this as the finite element mesh size, values for $C$ and $D$ are obtained in a trial and error set of calculations that eventually reproduce adequately the experimental notched-bar data.

(iii) These values of $C$ and $D$ are then used in numerical study of the crack growth data, where the mesh size is adjusted until acceptable agreement is achieved.

(iv) The new value of $L$ together with the previously chosen values of $C$ and $D$ are used in a re-computation of the notched-bar tests. If the results of this are acceptable then the damage mechanics tuning has been accomplished. If not, steps (ii)-(iv) are repeated.

\section{ADDITIONAL REFERENCES}

A1. B. A. Bilby, I. C. Howard and S. H. Li, Prediction of the first spinning cylinder test using ductile damage theory, Fatigue Fracture Engng Mater. Structures, 16 (1992) 1-20.

A2. Z. H. Li, B. A. Bilby and I. C. Howard, A study of the internal parameters of ductile damage theory, submitted to Fatigue Fracture Engng Mater. Structures.

A3. I. C. Howard, Z. H. Li and B. A. Bilby, Ductile crack growth predictions for large centre cracked panels by damage modelling using 3-D finite element analysis, submitted to Fatigue Fracture Engng Mater. Structures. 